\author{
Діана ЛАРЧЕНКО, \\ orcid.org/0000-0002-6118-8372 \\ асистент кафедри мов і літератур Далекого Сходу та Південно-Східної Азї \\ Інституту філології \\ Київського начіонального університету імені Тараса Шевченка \\ (Київ, Україна) dianalarchenko@yahoo.com
}

\title{
СТРУКТУРНИЙ АНАЛІЗ ФРАЗЕОЛОГІЗМІВ ІНДОНЕЗІЙСКОЇ МОВИ
}

У статті наведені і проаналізовані найужсианімі фразеологічні одиниці сучасної індонезійської мови. Розглянуто основні джерела походження фразеологізмів та їх історичне підтрунтя. Завдяки цьому проведена класифікачія фразеологічних одинищь сучасної індонезійської мови. Наведені найяскравіші приклади для кожної групи з варіантами перекладу українською мовою. Показані приклади дослівного перекладу та можливі відповідники в украӥнській мові. Фразеологічний склад індонезійської мови розділений на своєрідні групи, відповідно до активності вживання тих чи інших одиниць у різних мовленнєвих ситуаџіях. Розкрито причини та мотиви використання певних фразеологічних виразів у сучасній індонезійській мові. 3 точки зору семантики проаналізовано окремі слова з перекладом, які зустрічаються найчастіше у фразеологічних сполуках індонезійської мови, та проведена паралель значень для таких груп. Особливу увагу приділено метафорам індонезійської мови, оскільки ці сполуки викликають найбільший інтерес серед лінгвістів, із наведеними перекладами та відповідниками в украӥнській мові. Метафори взяті з різних фразеологічних груп і досліджені відповідно до джерела їхнього походження. Кожна одиниия окремо детально розглянута та проаналізована, а також підібрані кілька вдалих варіантів перекладу украӥнською мовою для повного розуміння кожної метафори в індонезійській мові. Детально розглянуті та наведені влучні аналізи для усіх представлених груп фразеологічних одиниць із позитивними, негативними та нейтральними конотачіями. Кожна група представлена широким рядом фразеологічних сполук та наведеними прикладами перекладу українською мовою. У статті також наведені лексеми фразеологічних одиниць та особливості їх вжсвання в сучасній мові. Усі лексеми поділені на різні групи відповідно до сфери їх вживання в індонезійській мові та частоти використання. Розглянуто ефекти фразеологічної омонімії, синонімії та антонімії в індонезійській мові з численними прикладами та найбільш вдалими відповідниками в українській мові. Кожна група ретельно описана та проаналізована. Зазначені лінгвісти та дослідники цих тем із прикладами їхніх праць.

Ключові слова: фразеологічна одиничя, прислів'я, приказка, ідіома, вислів, повчання, метафора, фразеологічний вираз, класифікачія.

\author{
Diana LARCHENKO, \\ orcid.org/0000-0002-6118-8372 \\ Teaching Assistant at the Department of Languages \\ and Literatures of the Far East and Southeast Asia \\ Institute of Philology \\ of Taras Shevchenko National University of Kyiv \\ (Kyiv,Ukraine)dianalarchenko@yahoo.com
}

\section{STRUCTURAL ANALYSIS OF INDONESIAN PHRASEOLOGIES}

The article presents and analyzes the most common phraseological units of the modern Indonesian language. The main sources of origin of phraseology and their historical basis are considered. Due to this, the classification of phraseological units of the modern Indonesian language is carried out. Here are the most striking examples for each group with options for translation into Ukrainian. Examples of literal translation and possible language equivalents in the Ukrainian language are shown. The phraseological structure of the Indonesian language is divided into peculiar groups, according to the activity of using certain units in different speech situations. The reasons and motives for the use of certain phraseological expressions in the modern Indonesian language are revealed. From the point of view of semantics the separate words with translation which meet most often in phraseological connections of the Indonesian language are analyzed and the parallel of values for such groups is carried out. Particular attention is paid to the metaphors of the Indonesian language, as these compounds are of the greatest interest among linguists and linguists, with the above translations and equivalents in the Ukrainian language. Metaphors are taken from different phraseological groups and studied according to their source of origin. Each unit is considered and analyzed in detail, as well as several successful versions of translation into Ukrainian for a full understanding of each metaphor in the Indonesian language. Accurate analyzes for all presented groups of phraseological units with positive, negative and neutral connotations are considered in detail and given. Each group is represented by a wide range of phraseological compounds and examples of translation 
into Ukrainian. The article also presents the tokens of phraseological units and features of their use in modern language. All tokens are divided into different groups according to their field of use in the Indonesian language and frequency of use. The effects of phraseological homonymy, synonymy and antonymy in the Indonesian language are considered with numerous examples and the most successful equivalents in the Ukrainian language. Each group is carefully described and analyzed. These linguists and researchers of these topics with examples of their work.

Key words: phraseological unit, proverb, saying, idiom, expression, teaching, metaphor, phraseological expression, classification.

Постановка проблеми. Фразеологія невід'ємний і особливо виділений компонент мови, найяскравіший, своєрідний, «індивідуальний», культурно значимий і національно специфічний, здатний концентровано висловити не тільки особливості мови, але і їі носіїв, їхнє світовідчуття, склад розуму, менталітет, національний характер і стиль мислення. Без сумніву, фразеологія додає мові яскравості, неповторності і національного колориту, що відрізняє одну мову від іншої.

Кожен фразеологізм сприймається як невід'ємний складник буття, що є ключем до пізнання будь-якої культури світу. Як свідчить аналіз лінгвістичної літератури, фразеологічний базис індонезійської мови залишається малодослідженим. Тому набуває особливої актуальності вивчення фразеологічної скарбниці сучасної індонезійської мови 3 лінгвістичної та структурносемантичної точки зору.

Аналіз досліджень. Вже майже протягом століття фразеологія досліджується як українськими, так i зарубіжними вченими, про що свідчить велика кількість літератури, що присвячена цьому питанню.

3 одного боку, цей розділ мови досліджений досить добре і глибоко. Але при всьому різноманітті і різнобічності теоретичних напрямів вчені намагаються проаналізувати дані для уточнення деяких властивостей фразеологічних одиниць, визначення їхньої ролі та функцій у мові.

Проте пласт індонезійської фразеології і досі залишається непаханим полем для дослідників, тому викликає особливий інтерес у сучасних вчених та лінгвістів.

Двоє 3 авторів, Бурханудін та Чаер, стверджують, що фразеологічні одиниці в індонезійській мові мають значну комунікативну силу (Burhanuddin, 1996; Chaer, 1990), оскільки використовуються здебільшого в побутовій мові. Дослідник В. Д. Аракін фокусується на особливостях виникнення індонезійських фразеологізмів і пропонує широку інтерпретацію їхніх функцій (Аракин, 1972). Такі лінгвісти, як Алвасілах та Бадуду, підтримують ідею комунікативної парадигм у розумінні фразеологічних словосполучень у сучасній індонезійській мові (Alwasilah, 1985; Badudu, 1992).
Вивчення фразеологічних одиниць - досить цікавий пласт для дослідження в індонезійській мові, адже багата історія та постійні зміни колоністів дають ще ширший спектр для вивчення. Дослідник Бадуду описує історію походження фразеологізмів індонезійській мові. Лінгвіст Амік вважав найбільш цікавими фразеологізми, взяті з європейської культури: із французької, голландської, італійської, іспанської та португальської мов (Amik, 2012). Вчений Братаатмаджа описав контакти індонезійської мови з країнами Азії (Brataatmadja, 1982).

Мета статті - проаналізувати та охарактеризувати власне структуру та семантику фразеологізмів індонезійської мови.

Виклад основного матеріалу. Фразеологічні сполуки несуть інформацію про культуру країни. Для виявлення лінгвокультурної своєрідності було зафіксовано 285 найуживаніших фразеологічних одиниць та типізовано їх за різними тематичними групами.

Що стосується походження цих фразеологізмів, можна виділити такі джерела:

1) запозичені 3 інших мов/культур. Численні ФО індонезійської мови були запозичені з іноземних мов. Історично міграційні хвилі з Індії, Китаю, Португалії, Аравії та Нідерландів відігравали центральну роль у розвитку релігійного та культурного різноманіття Індонезії. Разом із цією міграцією багато книг та історій були перекладені індонезійською, таким чином впливаючи на багатство релігійних ідіом. Своєю чергою вони поділяються на групи:

- ФО, що мають арабське походження: "kitabsuci" - «свята книга»;

- ФО індуїстсько-буддійського походження: "hukumkarma" - «закон карми»;

- ФО біблійного походження: "roti hidup" «хліб щоденний», "benih perselisika” - «яблуко розбрату», "roti bukanlah segala-galanya" - «не хлібом єдиним живе людина»;

- ФОєвропейськогопоходження:"bulanmadu”«медовий місяць», "polisitidur" - «сплячий поліцейський», “menutupmata" - «померти»;

- ФО китайського походження: “masukangin”«захворіти», “anginduduk" - «хронічний нежить»;

- ФО малайського походження: "jangan belajar orang tua makan dadih/kerak" - «не вчи вченого їсти хліба печеного»; 
- ФО сунданського походження: "kecil cabai rawi” - «маленький та сміливенький»;

2) фразеологізми, що утворилися з оповідань, казок: "silih-silih kambing" має балійське походження і означає людину, яка позичає будь-що, але не повертає це назад, а сунданська ФО "kambing keras kepala" («впертий баран») означає нескромну, вперту людину;

3) ФО, що мають історичне походження. Численні індонезійські фразеологічні одиниці походять від тогочасних історичних подій. Наприклад, ФО “hidung belang” («смугастий ніс»), що означає «бабій», виник у Батавії у XVII столітті на початку голландського колоніального періоду. Голландські солдати жили на індонезійському архіпелазі протягом багатьох років без своїх дружин або інших близьких. Пітер Кортенгоф, солдат генерала-губернатора Дж. П. Коена, був втягнений у сексуальний скандал, визнаний винним та ув'язнений. Перед виходом із залу суду Коен позначив нос Кортенгофа вугіллям, залишивши чорну смужку. 3 тих пір сталий вираз "hidung belang" став позначати бабія.

Ідіома "semangat empat lima" - «дух сорок п'ятого» походить із періоду проголошення незалежності Індонезії в 1945 році і стосується сильного і пристрасного духу націоналістичних бійців, які боролися за збереження незалежної нації. Ця ідіома означає «палаючу пристрасть»;

4) ФО 3 літературних творів. В індонезійській мові $\epsilon$ лише кілька ідіом, взятих із літератури. Одним із них є "bukan zaman Sitti Nurbaya" - «не час Сітті Нурбайя», що означає «вже не період для укладених шлюбів». Ця ідіома взята 3 роману Мараха Руслі «Сітті Нурбайя», в якому розповідається про молоду дівчину, чий укладений шлюб закінчився трагедією. Більшість літературних творів використовують ідіоми, які вже знаходяться в суспільстві. У романі Ландіта Кресни Харіаді «Гаджах Мада» ідіома "pagi buta" - «сліпий ранок» означає «дуже рано вранці, коли ще трохи темно».

Також усталеними виразами 3 літературних творів є ФО “jantunghati” - «коханий», «улюблений», “kembangkeluarga" - «улюбленець сім'ї» та "bijimata" - «найдорожчий»;

5) ФО, утворені від прислів'їв, приказок, висловів 3 усно-побутового мовлення народу, наприклад "jika pandai menggulai badar punja ditenggiri” - «у розумної людини все завжди виходить», “minum cuka pagi hari” - «робити справу, що викликає у людини відразу», "air susu dibalas dengan air tuba" - «на добро відповісти злом», "makangaram" - «набиратися досвіду»;
6) ФО з виробничо-побутового життя: “padiditanam, tumbuhlalang" - «зазнати великих втрат», "jika tidak dipecah ruyung, di mana boleh mendapat sagu” - «щоб досягти мети, треба працювати»;

7) ФО з дотепного народного мовлення (20,3\%): "makanpancing" - «бути обманутим»; "sebagai kacang direbus satu" - «стрибати від радощів»; "berminyakair" - «лестити».

Лексико-семантична група представлена 122 одиницями з різним ступенем активності, що дає змогу їх об'єднати в окремі групи:

1) фразеологізми 3 дуже низьким ступенем фразеологічної активності, які входять до складу однієї фразеологічної одиниці: "kusut”, “anjung”, "awan", "asrama”, "daging”, "batu”, "bekerja”, "bau”, "roti”, "basah”, "benih”, "burung”, "polisi”, що становитт 20,7\%;

2) фразеологізми з низьким ступенем фразеологічної активності, що входять до складу 2-5 фразеологізмів: "hujan", "nasi”, “akal”, "bawang”, "angin", "merah", "langit”, "tangan", "garam”, "bibir", "hitam", “merah", "bibir", "mulut”, "anak", "tulang” та фразеологізми 3 дієслівним компонентом "angkat" - 42,1\%;

3) середній ступінь фразеологічної активності, що зустрічаються у 6-10 одиницях, мають фразеологізми з основним компонентом "air", “mulut”, "garam", "hitam”, "bunga”, "bulan”, "tanah", “ hijau" $-15,7 \%$;

4) фразеологізми з високим ступенем активності, що входять до складу 10 та більше одиниць: "ayam", "garam", "padi”, "hati”, "mata”, "tangan" та фразеологізми 3 дієслівним компонентом “makan”. Ця група становитт 21,5\% від дослідженого матеріалу.

При цьому фразеологічні одиниці з головним компонентом "hati” становлять 5,96 \% від відібраного матеріалу, з компонентами "tangan", “ayam” ma "mata” - 3,8\%, 3,6\% і 3,6\% відповідно.

Найбільш активно в індонезійській мові функціонують фразеологізми 3 компонентами «їсти», «очі», «серце». Мовний феномен такої високої активності компонентс «їсти» у фразеологічних сполученнях може бути пояснений тим, що приготування та вживання їжі для індонезійців було дуже важливим сакральним дійством. Коли людина їсть, то вона отримує священну енергію, життєві сили.

У формуванні семантики ФО на позначення почуттів людини в індонезійській мові сильну позицію займають фразеологізми з компонентами "hati", що може перекладатися українською як «душа» і «серце». Лексема «серце» має переносне значення як місце зосередження почуттів, хвилювань, вчинків людини. Проаналізувавши фразе- 
ологізми 3 компонентом «серце» на позначення почуттів людини, ми виявили, що досліджувані одиниці утворюють групи позитивних та негативних почуттів.

Однією з форм прояву вторинної номінації $є$ метафора - перенесення назви одного предмета на інший на основі якоїсь подібності. Перенесення назви за подібністю присутнє в багатьох мовах, у тому числі в індонезійській. Стосовно відібраних найуживаніших фразеологізмів, ми можемо зазначити, що найбільш часто вони використовуються з метою охарактеризувати людину. У зібраному матеріалі зустрічаються фразеологічні одиниці, які таким чином характеризують людину:

- якості характеру: “berattangan” - «ледащо», "makan bawang" - «сердитий, злий»; "berminyak muka" - «радісний, задоволений», “darahhangat" «запальний»;

- розумові здібності: "makan dalam" - «глибокодумний»; "padi sekepuk", "hampa" - «пуста, глупа людина»;

- людські негативні риси: "makan emas/ duit" - «брати хабарі»; “makan tidur" - «ледарювати»; "salahair" - «невихований»; "tinggihati" «зарозумілий»;

- характеристика зовнішності: "sebagai cendawan dibasuh/disesah" - «блідий»; "sebagai dasun tunggal" - «про красиво загострений ніс», "berbadandua" - «бути вагітною»;

- матеріальний стан: "aus telunjuk menedek garam" - «пальці стерлися від солі» (про бідну людину); “ayam bertelur di padi” - «як сир у маслі»; "gulungtikar" - «банкрут»;

- сумісність/несумісність людей: “hidup sebagai asam dengan garam" - «підходити один одному»; " minyak dengan air" - «несумісні люди»;

- рід діяльності, хобі: "makanpena"- «заробляти на життя літературною працею», “kutubuku” - «людина, що любить читати».

Деякі компоненти ФО викликають ув індонезійців певні асоціації, характерні для всієї нації загалом. Уявлення про певні властивості та характер вкоренилися у свідомість цього народу. Деякі компоненти ФО набули стійкого переносного значення, що передусім пов'язане 3 культурними традиціями Індонезії, ставленням до того чи іншого явища та, звісно, особливостями менталітету. Наприклад, компонент “madu” («мед») у фразеологічних сполученнях, що були зібрані для дослідження, отримує в основному позитивну конотацію: “berbulan madu” - «медовий місяць»; “laut madu berpantai sakar" - присл. «тільки мудра людина може говорити про гарні речі». Компонент “kambing” («баран») у дослі- дженні знаходить лише негативну конотацію: "kambinghitam" - «цап-відбувайло», "kambing keraskepala" - «вперта людина».

Також важливим елементом структури фразеологічного матеріалу є шкала оцінки, за якою він поділяється на фразеологізми з негативним, позитивним та нейтральним забарвленням. Усі представлені фразеологізми можна поділили на 3 види залежно від емоційного забарвлення:

- фразеологічні одиниці з негативною конотацією:"membuanggaramkelau” (дослівно-«кинути сіль у воду») - «робити марну справу»; “makan berulam” («їсти рис зі свіжою зеленню») - «зрадити подружні стосунки»; “kutuloncat” («блоха, що стрибає») - «продажна людина»;

- фразеологічні одиниці з позитивною конотацією: “makan dalam” («глибоко їсти») - «глибокодумний»; "sekain sebaju, selauk senasi" («ходять в одній сорочці та їдять 3 однієї миски») - «про нерозлучних друзів»; “tenaga badak" («сильний як носоріг») - «дуже сильний»;

- фразеологічні одиниці з нейтральною конотацією: "makan pena” («їсти ручку») - «заробляти на життя літературною працею»; "garam hidu" («життєва сіль») - «життєвий досвід».

У процесі аналізу можна звернути увагу на те, що фразеологізми з лексемами “garam”, “madu”, “bunga”, "padi”, “roti” мають в основному позитивну конотацію: "sebagai asam dengan garam" («як щось кисле з сіллю») - «дуже підходити один одному»; “lautan madu" («океан меду») - «дуже милий, привабливий, спокусливий»; “bunga kampong” («квітка села») - «про привабливу зовнішність дівчини»; "jika ada padi segalanya terjadi" - присл. «якщо є рис, то всі бажання здійснюються»; "rotihidup" - «хліб насущний»; "garam jatuh ke air" («сіль потрапила у воду») «порада пішла на користь».

Фразеологізми 3 таким компонентом, як “bawang”, вживаються в негативному значенні: “pemakan bawang” («той, що їсть цибулю») - «зла, недобра людина»; “"anak bawang”” («дитя цибулі») «новачок, вигнанець».

Однак у деяких фразеологізмах семантика не залежить від значення основного компонента i може бути як позитивною )“sebagai kacang direbus satu” - «стрибати від радощів»; "mendapat pisang terkubak" - «неочікувано пощастити»), так і негативною ("makan emas" («їсти золото») - «брати хабарі»; "air diminum rasa duri, nasi dimakan rasa sekam" - присл. «страждати від лиха або ж бути дуже сумним»; "kacang yang melupakan kulitnya" «людина, яка забула про тих, хто їй колись допомагав»; “awak kurus, daging menimbun” - «багата 
людина, що прикидається бідною»), або ж може мати нейтральну семантику ("makan angin" «гуляти»; "sebagai cendawan di musim hujan" - «як грибів у сезон дощів» («багато»)).

Основна частина фразеологізмів $є$ однозначною, але тим не менш вони можуть ставати багатозначними. Багатозначність фразеологізмів, як правило, пов'язана з омонімією (як внутрішньою, так і зовнішньою). Однак омоніми всередині фразеологічної одиниці є доволі рідкісним явищем, що викликано лексичною вторинністю фразеологізму та невеликою кількістю багатозначних сталих сполук. У зібраних нами фразеологізмах із лексемами для позначення харчових продуктів більш широко представлена зовнішня фразеологічна омонімія, тобто омонімія між фразеологізмом та вільним словосполученням, що знаходиться поза фразеологічною системою:

- “makan bawang" - як вільне словосполучення (ВС) - «їсти цибулю», як фразеологізм (ФО) - «сердитий, злий»;

- “makan benak" - як ВC - «їсти кістний мозок», як ФО - «крупно нажитися»;

- “makan dedek (dedak)” - як ВС - «харчуватися висівками», як ФО - «жити впроголодь, голодувати».

- "biang keladi" - як ВС - «бульба таро», як ФО - «корінь, причина».

Незважаючи на те, що досліджуваний матеріал становить невелику кількість фразеологічних одиниць та прислів'їв, у ньому зустрічаються такя явища, як синонімія та антонімія. Синонімічними є такі фразеологізми: "banyak makan asam garam та banyak menelan garam hidup", які мають значення «багато пережити тяжкого у житті»; "tanahair" та "tanah tumpah darah" - «Батьківщина»; "jangan diajarorang tua makan dadih/kerak" та "belajar orang tua makan bubur" $є$ аналогом українського вислову «не вчи вченого їсти хліба печеного»; "kecil cabairawit" i "kecil ladaapi" - «маленький та сміливенький»; "air diminum rasa duri, nasi dimakan rasa sekam" i "air diminum sembiluan" - «бути дуже сумним, занепокоєним чимось»; "kena-kena seperti santan bergula" та "sebagai asam dengan garam"- «бути під стать один одному»; “makan emas" та "makan besar" - «брати хабарі»; "memberigaram kepada laut" та "anjing diberi makan nasi tak kan kenyang"«виконувати непотрібну роботу»; "seperti minyak dengan air" та "seperti sayur dengan rumput" - «не підходити один одному»; “di luar bagai madu, di dalam bagai empedu, buahyang manis berulat didalamnya" та "mulut disuapi pisang, pantat dikait dengan onak"- «не все те золото, що блищить». Антонімічні фразеологізми також зустрічаються: "tangan dingin" («щасливчик») та "tangan panas" («невезучий»), "sebagai asam dengan garam" («бути під стать один одному») та "seperti sayur dengan rumput" («несумісні»); "makan dedak" («голодувати») та "seperti tikus jatuh di beras" («як сир у маслі»); "seperti kacang direbus satu" («стрибати від радощів») та "air diminum sembiluan" («бути дуже сумним»); “makan benak" («дуже нажитися») та "padi ditanam, tumbuh ilalang” («зазнати серйозних втрат»).

Висновки. Фразеологія - це наука про фразеологічні одиниці (ФО), тобто про стійкі поєднання слів з ускладненою семантикою, які не утворюються за породженими структурно-семантичними моделями змінних сполучень.

Фразеологізм - стійке поєднання лексем із повністю або частково переосмисленим значенням. Основними і універсальними ознаками ФО $€$ стійкість, ідіоматичність, окремооформленість.

Був проведений відбір фразеологізмів із лексемами для позначення їжі та структурно-семантичний аналіз відібраних одиниць. Загалом було опрацьовано 285 найуживаніших фразеологічних сполук та прислів'їв, приказок індонезійської мови. У процесі аналізу були виділені фразеологізми 3 позитивною, негативною та нейтральною конотацією, також було проведено групування за кількісною ознакою. Отже, лексично-семантична група представлена 122 одиницями 3 різним ступенем активності. Найбільш активно в індонезійській мові функціонують фразеологізми з компонентами «їсти», «очі», «серце».

У межах цього фразеологічного матеріалу прослідковується явище омонімії, синонімії та антонімії.

За походженням більшість фразеологізмів - це застиглі народні метафори, порівняння, прислів'я та приказки 3 усно-побутового та виробничопобутового життя.

Фразеологія в індонезійському контексті є порівняно молодою дисципліною і в основному базується на європейській науковій думця. Незважаючи на це, значна кількість провідних лінгвістів Індонезії вже виробили власні підходи до аналізу та класифікації ФО. 


\section{СПИСОК ВИКОРИСТАНИХ ДЖЕРЕЛ}

1. Алефіренко М. Ф. Теоретичні питання фразеології. Харків : Вища школа, 1987. 133 с.

2. Аракин В. Д. Грамматика индонезийского языка. Москва : Наука, 1972. 462 с.

3. Аракин В. Д. Индонезийские языки. Москва : Наука, 1965. 152 с.

4. Alwi H. Tata Bahasa Baku Bahasa Indonesia. Edisi Kedua. Jakarta : Balai Pustaka, 1998. 486 c.

5. Amik P. C. Idiom bahasa Prancis dan bahasa Indonesia yang bermakna kepribadian manusia (studi komparatif). Yogyakarta : Universitas Negeri Yogyakarta, 2012. 105 c.

6. Badudu J. Belajar Memahami Peribahasa. Bandung : CV Pustaka Prima, 1983. 188 c.

7. Badudu J. S. Kamus peribahasa. Memahami arti dan kiasan peribahasa, pepatah, dan ungkapan. Jakarta : Kompas, 2008. $36 \mathrm{c}$.

8. Badudu J. Peribahasa, Salah Satu Segi Bahasa yang Masih Perlu Diberi Perhatian. Jakarta : Pusat Pembinaan dan Pengembangan Bahasa, 1988. $201 \mathrm{c}$.

9. Brataatmadja H. Kamus 2000 Peribahasa. Yogyakarta : Kanisius, 1982. $143 \mathrm{c}$.

10. Burhanuddin, E. Idiom dalam Bahasa Minangkabau: Telaah Bentuk dan Maknanya. Jakarta : Tesis Universitas Indonesia, 1996. $234 \mathrm{c}$.

11. Chaer A. Kamus Idiom Bahasa Indonesia. Flores : Nusa Indah, 1986. 193 c.

12. Chaer A. Pengantar semantik bahasa Indonesia. Jakarta : Rineka Cipta, 1990. 189 c.

13. Chaer A. Sintaksis Bahasa Indonesia: Pendekatan Proses. Jakarta : Rineka Cipta, 2009. 256 c.

14. Dardjowidjojo, S. Beberapa Aspek Linguistik Indonesia. Jakarta : Djambatan, 1983. 80 c.

15. Isriqomah N. Analisis penerjemahan idiom bahasa Indonesia ke dalam Bahasa Jepang. Jakarta : UI, 2008.65 c.

16. Khak A. Idiom dalam bahasa Indonesia: struktur dan makna. Yogyakarta : Balai Bahasa, 2008. 16 c.

\section{REFERENCES}

1. Alefirenko M. F. Teoretichni pitannya frazeologii. [Theoretical questions of phraseology]. Higher school, 1987, 133 p. [in Ukrainian].

2. Arakin V. D. Grammatika indoneziyskogo yazika. [Grammar of the Indonesian language]. Nauka, 1972,462 p. [in Russian].

3. Arakin V. D. Indonesiyskiye yaziki. [Indonesian languages]. Nauka, 1965, 152 p. [in Russian].

4. Alwi H. Bahasa Baku Bahasa Indonesia. Edisi kedua. [Indonesian Language Standard Grammar. Second Edition]. Balai Pustaka, 1998, 486 p. [in Indonesian].

5. Amik P. C. Idiom bahasa Prancis dan bahasa Indonesia yang bermakna kepribadian manusia (studi komparatif). [Idioms in French and Indonesian that mean human personality (comparative study)]. Yogyakarta State University, 2012, 105 p. [in Indonesian].

6. Badudu J. Belajar Memahami Peribahasa. [Learn to Understand Proverbs]. CV Pustaka Prima, 1983, 188 p. [in Indonesian].

7. Badudu J. S. Kamus peribahasa. Memahami arti dan kiasan peribahasa, pepatah, dan ungkapan. [Proverb dictionary. Understand the meaning and allusion of proverbs and expressions]. Kompas, 2008, 36 p. [in Indonesian].

8. Badudu J. Salah Satu Segi Bahasa yang Masih Perlu Diberi Perhatian. [Proverb, One Aspect of Language that Still Needs Attention]. Center of Language Development, 1988, 201 p. [in Indonesian].

9. Brataatmadja H. Kamus 2000 Peribahasa. [Dictionary of 2000 Proverbs]. Kanisius, 1982, 143 p. [in Indonesian].

10. Burhanuddin, E. Idiom dalam Bahasa Minangkabau: Telaah Bentuk dan Maknanya. [Idioms in Minangkabau Language: Study of Forms and Meanings]. University of Indonesia, 1996, 234 p. [in Indonesian].

11. Chaer A. Kamus Idiom Bahasa Indonesia. [Dictionary of Indonesian Idioms]. Nusa Indah, 1986, 193 p. [in Indonesian].

12. Chaer A. Pengantar semantik bahasa Indonesia. [Introduction to Indonesian semantics]. Rineka Cipta, 1990,189 p. [in Indonesian].

13. Chaer A. Sintaksis Bahasa Indonesia: Pendekatan Proses. [Indonesian Syntax: Process Approach]. Rineka Cipta, 2009, 256 p. [in Indonesian].

14. Dardjowidjojo, S. Beberapa Aspek Linguistik Indonesia. [Some Aspects of Indonesian Linguistics]. Djambat, 1983, 80 p. [in Indonesian].

15. Isriqomah N. Analisis penerjemahan idiom bahasa Indonesia ke dalam Bahasa Jepang. [Analysis of the translation of Indonesian idioms into Japanese]. UI, 2008, 65 p. [in Indonesian].

16. Khak A. Idiom dalam bahasa Indonesia: struktur dan makna. [Idioms in Indonesian: structure and meaning]. Balai Bahasa, 2008, 16 p. [in Indonesian]. 